\title{
NFKB2 gene expression in patients with peptic ulcer diseases and gastric cancer
}

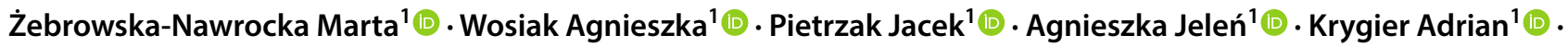

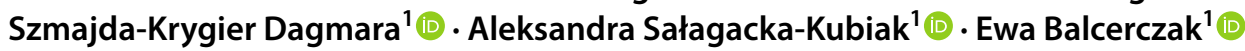

Received: 19 November 2019 / Accepted: 31 January 2020 / Published online: 13 February 2020

(c) The Author(s) 2020

\begin{abstract}
Gastric cancer is one of the most common worldwide types of cancer. It is a multifactorial disease and both environmental and genetic factors play an important role in its etiology. Evaluation of the relative expression level of $N F K B 2$ gene in two groups of patients: peptic ulcer and gastric cancer and its role in the pathomechanism of these diseases was the aim of this study. RNA was isolated from: 79 samples of peptic ulcer, 22 gastric cancer and 11 control tissue. The real-time PCR technique was used to study the expression of $N F K B 2$ gene. The relative expression level of $N F K B 2$ gene was a variable in all three studied groups. The relative $N F K B 2$ gene expression depends on the type of a disease. Peptic ulcer cases showed the increased relative $N F K B 2$ gene expression to control group $(p=0.0000)$. Cancer cases presented decreased relative $N F K B 2$ gene expression to normal stomach tissue $(p=0.0183)$. There are statistically important differences in the investigated gene expression between peptic ulcer, where the expression level is higher comparing to gastric cancer and control tissue which confirmed that such an activation is connected with an inflammatory process. The relative expression level of $N F K B 2$ is decreased in cancer cases as opposed to control tissue and peptic ulcer cases which could suggest that during carcinogenesis of gastric cancer inhibition of NF-kB pathway takes place which could be a promising factor for patients.
\end{abstract}

Keywords Expression $\cdot$ Peptic ulcer $\cdot N F K B 2 \cdot$ Gastric cancer $\cdot$ Real-time PCR

\section{Introduction}

Gastric cancer is the fourth most common cancer incident and the second cause of cancer death, about 738,000 each year [1]. The incidence rates vary wildly between men and women, in men the rates are two- to threefolds higher than in women, among nations are observed more frequently in East Asia, East Europe and South America [1]. Gastric cancer is a multifactorial disease and both environmental and genetic factors play an important role in its etiology, but the mechanism of pathogenesis is still unclear. Some of the risk factors, such as age and sex are not modifiable, whereas smoking and Helicobacter pylori infection could be changed [2]. There are still many gaps in our knowledge

Agnieszka Jeleń agnieszka.jelen@umed.lodz.pl

1 Laboratory of Molecular Diagnostics and Pharmacogenomics, Department of Pharmaceutical Biochemistry and Molecular Diagnostics, Medical University of Lodz, Lodz, Poland concerning causes, early detection of gastric cancer and its connection with chronic peptic ulcer disease, that is why dysregulation of several genes and pathways that could play an essential role during gastric carcinogenesis, like Wnt/ $\beta$ catenin, Hippo and Notch signalling, nuclear factor-kB in peptic ulcer and gastric cancer development should be investigated [3, 4]. NF-kappa-B is a transcription factor present in almost all cell types and is the endpoint of a series of signal transduction events that are initiated by a vast array of stimuli related to many biological processes, such as: inflammation, immunity, differentiation, cell growth, tumorigenesis and apoptosis. NF-kB is a family of bipartite transcription factors that include NFkB1, NFkB2, c-Rel, RelA, and RelB [5]. NF-kappa-B is controlled by various mechanisms connected with post-translational modification, interactions with other factors or inhibitors like NF-kappa-B inhibitor (I-kappa-B) family that kept NF-kappa-B in the cytoplasm as an inactive form $[6,7]$. I-kappa-B is phosphorylated by I-kappa-B kinases (IKKs), subsequently degraded, thus releasing the active NF-kappa-B complex which translocates to the nucleus $[8,9]$. NF-kB is activated by inflammatory 
factors like like IL-8 also by $H$. pylori infection during the development of peptic ulcer through IkB kinase complex phosphorylates IkB, and then degradation of IkB [10]. Also HuR, a RNA-binding factor that is a direct transcript target of NF-kB is activated in gastric cancer cell lines, its activation has proliferative and anti-apoptotic effects on gastric cancer [11]. The modified expression of NF-kB has antiapoptotic effects and leads to drug resistance in GC.

The aim of this study was to evaluate the relative expression level of $N F K B 2$ gene in two separate groups of patients: peptic ulcer and gastric cancer, connection with some clinically important parameters and its role in the pathomechanism of these diseases.

\section{Material and methods}

\section{Patients}

The investigated group consisted of two independent groups of patients. The first group comprised 79 RNA samples (43 females; 36 males; the median age of the group was 55 years) isolated from biopsies specimens of gastric mucosa taken during a routine gastroscopy test from patients with peptic ulcer diagnosed at the Department of Surgery, District Hospital, Leczyca Poland. The presence of Helicobacter pylori infection and its status was stated by rapid urease test, at the time of gastroduodenoscopy. The second group included 22 cases ( 8 females; 14 males; the median age of the group was 66 years) RNA samples isolated from tissue specimens taken during operations from patients with gastric cancer diagnosed at the Department of Pathology, Medical University of Lodz, Poland. 11 out of 22 normal tissue samples from patients were collected beyond the margin of cancer tissue. These 11 samples were considered macroscopically as healthy (control group). The investigation was in accordance with the principles of the Declaration of Helsinki and was approved by the Ethical Committee of the Medical University of Lodz (RNN/195/13/KE). All individuals included in the study gave their informed consent.

\section{Rapid urease test}

Diagnosis of Helicobacter pylori infection, only in the group of patients with peptic ulcer, was performed by rapid urease test (Institute of Food and Nutrition, Poland) at the time of gastroscopy. Mucosa collected from the antrum of the stomach during gastroscopy was placed into medium containing urea and an indicator such as phenol. The test uses the ability of $H$. pylori to secrete urease enzyme which breaks urea down to ammonium and bicarbonate. Ammonium raises the $\mathrm{pH}$ of test medium and changes the color of the specimen from yellow (negative) to red (positive).

\section{RNA isolation}

RNA was isolated by Total RNA Prep Plus Minicolumn Kit (A\&A Biotechnology, Poland) based on RNA isolation method developed earlier. The purity and concentration of RNA samples were assessed nanospectrophotometrically. Until analysis, RNA samples were stored at $-76^{\circ} \mathrm{C}$.

\section{Reverse transcription}

cDNA was transcribed from RNA according to High-Capacity cDNA Reverse Transcription Kit (Applied Biosystems; USA). For real-time PCR normalization UV absorbance was used to determine the amount of RNA added to a cDNA reaction. PCRs were then set up using cDNA derived from the same amount of input RNA. The final concentration of RNA in reaction mixture was $0.005 \mu \mathrm{g} / \mu \mathrm{L}$. As a reference gene, the GAPDH, encoding glyceraldehyde-3-phosphate dehydrogenase, was used. Before the quantitative analysis of gene expression during the real-time PCR reaction, parameters were checked using qualitative PCR. PCR reaction mixture for PCR amplification consisted of a cDNA template, with/adding $0.5 \mu \mathrm{M}$ of each primer, $5 \mu \mathrm{L}$ of $2 \times$ PCR Super MasterMix (Biotool.com; USA) water to a final volume of $20 \mu \mathrm{L}$. Negative control was included in each experiment (sample without a cDNA template).

\section{Real-time PCR}

Real-time PCR reactions were done using StrataGene, according to SYBR ${ }^{\circledR}$ Green JumpStart ${ }^{\mathrm{TM}}$ Taq ReadyMix ${ }^{\mathrm{TM}}$ protocol (Sigma Aldrich, Germany). The reaction mixture for both genes consisted of $0.5 \mu \mathrm{L}$ of each primer (NFKB2 F 5'-CCA TGA CAG CAA ATC TCC-3'; R 5'-TAA ACT TCA TCT CCA CCC C-3'; GAPDH F 5'-TGG TAT CGT GGA AGG ACT CAT-3', R 5'-ATG CCA GTG AGC TTC CCG TTC AGC-3'), $7.5 \mu \mathrm{L}$ SYBR-Green ReadyMix, $1 \mu \mathrm{L}$ of cDNA and distilled water up to the final volume of $16 \mu \mathrm{L}$. Samples were tested in triplicates and means of obtained $\mathrm{Ct}$ values for both genes were calculated. The reactions for $N F K B 2$ and GAPDH genes were carried out in separate tubes. In each experiment the negative control, also tested in triplicates, was included. The thermal cycling conditions comprised an initial denaturation step at $95{ }^{\circ} \mathrm{C}$ for $10 \mathrm{~min}$, 40 cycles of denaturation at $95{ }^{\circ} \mathrm{C}$ for $30 \mathrm{~s}$, annealing at 57 ${ }^{\circ} \mathrm{C}$ for $60 \mathrm{~s}$, elongation at $72{ }^{\circ} \mathrm{C}$ for $60 \mathrm{~s}$ and a final extension step at $72{ }^{\circ} \mathrm{C}$ for $3 \mathrm{~min}$. To calculate the relative changes in gene expression, the $\Delta \Delta \mathrm{C}_{\mathrm{q}}$ method was used [12]. 


\section{Statistical analysis}

Statistical analysis was performed using the STATISTICA version 12. (StatSoft, Inc., Tulsa, OK, USA) software package. To determine the validity between the R-value and age, gender or clinical and pathological factors the $U$ Mann-Whitney test was used. A $p$-value $<0.05$ was assumed as significant in all tests.

\section{Results}

The relative expression level of NFKB2 gene was successfully investigated in 79 samples from peptic ulcer, 22 samples of tissues from gastric cancer and 11 control samples of tissue macroscopically examined as healthy collected beyond margin of cancer tissue from gastric cancer patients.

\section{Expression of NFKB2 mRNA in peptic ulcer patients cohort}

The next part of the research pertained the determination of the relative level of $N F K B 2$ gene expression in relation to the $G A P D H$ gene in the peptic ulcer patients cohort. In this group of patients, the relative expression level of $N F K B 2$ among all cases was highly variable. The obtained results ranged from 0.1736 to 17.2328 . All results are presented in Table 1.

On the basis of rapid urease test results, a group of patients with peptic ulcer was divided into two subgroups: patients uninfected $(\mathrm{N}=47)$ and infected $(\mathrm{N}=32)$ with Helicobacter pylori. There were no statistically significant differences of the NFKB2 gene relative expression level between the subgroup of patients infected and uninfected with $H$. pylori $(p=0.7006)$ (Fig. 1$)$.

Additionally, the results of rapid urease test allowed to distinguish within the $H$. pylori-infected patients those in whom the severity of the infection was estimated as one, two or three pluses during semi-quantitative rapid urease test. Patients whose $H$. pylori infection severity was assessed as two or three pluses were combined into one subgroup. Next,

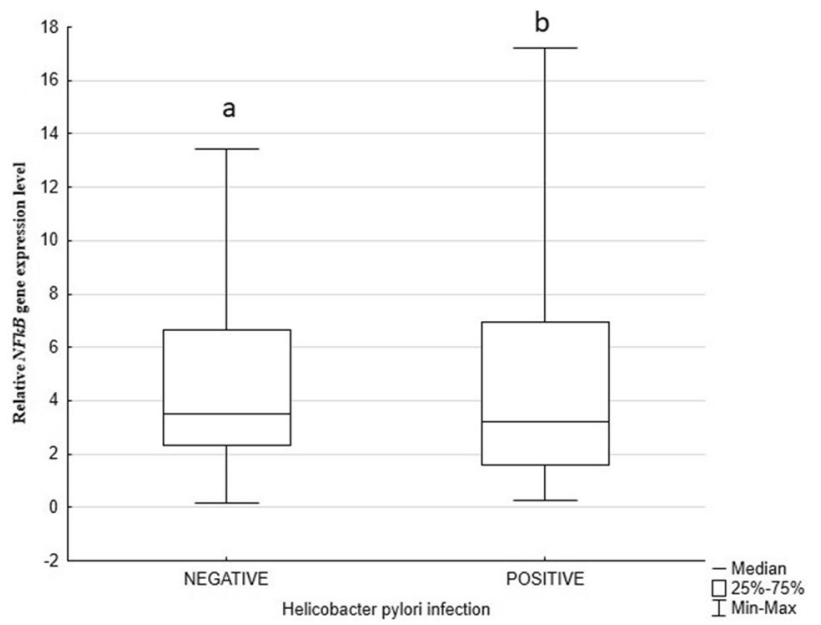

Fig. 1 Relative NFKB2 gene expression in peptic ulcer cells uninfected and infected with $H$. pylori. Figure shows the level of expression of the NFKB2 gene depending on the rapid urease test result: a negative-no $H$. pylori infection in the group of patients with peptic ulcer patients and $\mathbf{b}$ positive-current $H$. pylori infection in the peptic ulcer patients. The data plot $\mathbf{a}, \mathbf{b}$ for each of the rapid urease test results represents the median value along with the minimum and maximum values and the lower and upper quartiles

the relative expression levels of $N F K B 2$ gene were evaluated between this combined subgroup and the group of patients in whom the result was rated at one plus. There were no statistically significant differences $(p=0.8330)$.

Then, the relative expression of $N F K B 2$ mRNA, depending on gender and age in this group of patients was rated. No statistically significant differences were found $(p=0.7070$ and $p=0.1715$, respectively).

\section{Expression of NFKB2 mRNA in gastric cancer patients cohort}

In the second part of the study, the relative level of $N F K B 2$ mRNA was evaluated in the group of patients with gastric cancer. All results are presented in Table 2.

The dependences of the relative expression level of $N F K B 2$ with clinicopathological parameters were evaluated.
Table 1 Relative expression level of NFKB2 mRNA in peptic ulcer patients

\begin{tabular}{lllllll}
\hline Relative NFKB2 mRNA level & N & Median & Min & Max & Lower quartile & Upper quartile \\
\hline All cases & 79 & 3.4913 & 0.1736 & 17.2328 & 1.6269 & 6.6518 \\
Men & 36 & 3.3583 & 0.2571 & 13.3037 & 1.5418 & 6.7849 \\
Women & 43 & 3.6521 & 0.1736 & 17.2328 & 1.9504 & 6.6518 \\
Uninfected with H. pylori & 47 & 3.5278 & 0.1736 & 13.4272 & 2.3194 & 6.6518 \\
Infected with H. pylori & 32 & 3.2240 & 0.2571 & 17.2328 & 1.5874 & 6.9278 \\
Severity of infection assessed at (+) & 20 & 3.7966 & 0.2571 & 13.3037 & 1.5874 & 6.9278 \\
$\quad \begin{array}{l}\text { Severity of infection assessed at } \\
\quad(++) \text { and (+++) }\end{array}$ & 12 & 2.3912 & 0.5166 & 17.2328 & 1.7430 & 8.7130 \\
\hline
\end{tabular}


Table 2 Relative expression level of NFKB2 mRNA in stomach cancer patients

\begin{tabular}{lrlllll}
\hline $\begin{array}{l}\text { Relative } N F K B 2 \\
\text { mRNA level }\end{array}$ & $\mathrm{N}$ & Median & Min & Max & Lower quartile & Upper quartile \\
\hline All cases & 22 & 0.6558 & 0.2787 & 2.4095 & 0.4502 & 0.9343 \\
Men & 14 & 0.6298 & 0.3376 & 2.4095 & 0.3887 & 1.0307 \\
Women & 8 & 0.6774 & 0.2787 & 2.0663 & 0.5013 & 0.8375 \\
TNM Tis or I & 11 & 0.6879 & 0.2787 & 2.0663 & 0.5047 & 1.0307 \\
TNM II or III & 11 & 0.6072 & 0.3376 & 2.4095 & 0.3887 & 0.9343 \\
G1 & 11 & 0.6668 & 0.2787 & 1.7255 & 0.3803 & 0.7407 \\
G2 and G3 & 11 & 0.6072 & 0.3703 & 2.4095 & 0.4502 & 1.2300 \\
\hline
\end{tabular}

Table 3 Relative expression level of NFKB2 mRNA in morphologically normal tissue taken beyond the tumor margin

\begin{tabular}{lrlllll}
\hline $\begin{array}{l}\text { Relative } N F K B 2 \\
\text { mRNA level }\end{array}$ & $\mathrm{N}$ & Median & Min & Max & Lower quartile & Upper quartile \\
\hline All cases & 12 & 0.9964 & 0.4435 & 2.0618 & 0.7949 & 1.2200 \\
Men & 8 & 0.9964 & 0.4435 & 2.0615 & 0.8280 & 1.3419 \\
Women & 4 & 0.9617 & 0.7866 & 1.3198 & 0.7949 & 1.2200 \\
\hline
\end{tabular}

According to TNM stage the stomach cancer patients cohort was divided into two subgroups: patients with Tis or I stage and patients with II or III stage. There were no statistically significant differences between these two subgroups of patients $(p=0.3144)$. Next, in order to evaluate the differences of $N F K B 2$ gene expression level depending on histological grade, the group of patients with stomach cancer was divided into two subgroups: patients with low histological malignancy degree (G1) and patients with high histological malignancy degree (G2 or G3). The analysis between these two groups of patients was performed. However, no meaningful difference in the level of $N F K B 2$ gene expression was found ( $p=0.7928$ ) Following that, the relative expression of $N F K B 2$ mRNA, depending on gender and age in group of patients with stomach cancer was rated. No statistically significant differences were found $(p=0.3909$ and $p=0.3461$, respectively).

\section{Expression of NFKB2 mRNA in morphologically normal tissue taken beyond the tumor margin}

After that, the relative expression level of $N F K B 2$ mRNA in the morphologically normal tissue taken beyond the tumor margin was evaluated. The expression level was a variable in this group. Data is presented in Table 3.

\section{Expression of NFKB mRNA in samples from peptic ulcer, gastric cancer and control group}

Finally, samples were divided into three groups: peptic ulcer, gastric cancer and macroscopically normal gastric tissue which formed the control group. The analysis showed that relative $N F K B 2$ gene expression level depends on the

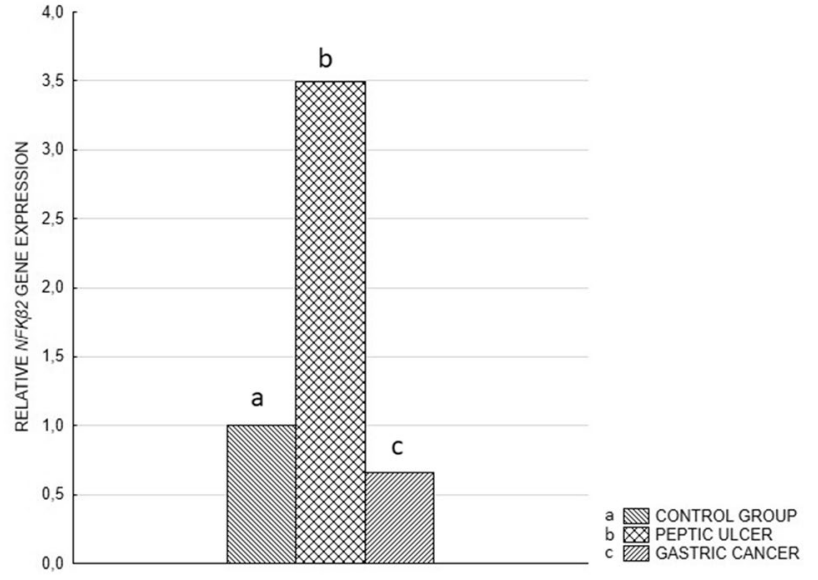

Fig. 2 Median relative $N F K B 2$ gene expression in peptic ulcer, gastric cases and the control group. Figure shows the dependence of the level of expression of the NFKB2 gene depending on the type of tissue in which the analysis was performed: a macroscopically normal gastric tissue (control group), b biopsies of the gastric mucosa (group of patients with peptic ulcer disease); $\mathbf{c}$ gastric cancer tissue (group of patients with gastric cancer)

type of tissue. Peptic ulcer cases showed the increased relative $N F K B 2$ gene expression to control group $(p=0.0000)$ (Figs. 2, 3). Then the difference in relative $N F K B 2$ gene expression between gastric cancer cases and control group was obtained. The results of this comparison showed that cancer cases present a decreased relative $N F K B 2$ gene expression as opposed to the control tissue $(p=0.0183)$ (Figs. 2, 3). Also the comparison between stomach cancer cells and peptic ulcer cases was performed and showed a statistically significant lower relative $N F K B 2$ gene expression 




Fig. 3 Relative $N F K B 2$ gene expression in peptic ulcer gastric cancer cases and the control group. Figure shows the dependence of the level of expression of the NFKB2 gene depending on the type of tissue in which the analysis was performed: a biopsies of the gastric mucosa, b gastric cancer tissue, c macroscopically normal gastric tissue. The data plot $\mathbf{a}, \mathbf{b}, \mathbf{c}$ for each of the tissues/study groups represents the median value along with the minimum and maximum values and the lower and upper quartiles

in cancer tissue compared to peptic ulcer cells $(p=0.0000)$ (Figs. 2, 3).

\section{Discussion}

The correlation between NF- $\mathrm{KB}$, its signals and gastric cancer phenotype remains unclear, as is the association of this activation with peptic ulcer disease development and progression, which could be one of the causes of gastric cancer. The aim of the study was to determine the level of NFKB2 mRNA in peptic ulcer and gastric cancer and compare the obtained results to control tissue, including other important clinical parameters, like presence of $H$. pylori infection, TNM staging and others.

Inappropriate $N F K B 2$ activation as a recurrent feature is well documented in MALT lymphomas, PMBL, multiple myeloma, and Hodgkin's lymphoma [13-16] and solid tumours $[17,18]$. In our study we showed that the level of mRNA is lower in patients with gastric cancer when compared to the control tissue or patients with peptic ulcer. Doffey et al. [19] observed that blocked Nf- $\mathrm{KB}$ function in head and neck squamous cell carcinoma cells could be important for inhibition of growth and metastases and showed that this inhibited xenograft-derived tumour growth. Inhibition of NF- $\mathrm{BB}$ in mutated Kras-induced lung cancer and pancreatic cancer greatly reduced tumour initiation and progression [20]. In this study no differences were observed between the gene expression level and some clinicopathological parameters, like clinical staging and histological grading, which could suggest lack of connection with worse prediction or prognosis for the patients, but it could be explained by a small group of investigated cancers. NFKB2 family consists of transcription factors that form homo- or heterodimerization of the

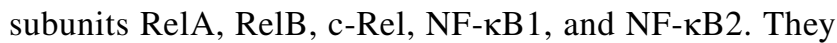
can be activated in two ways: classical and an alternative one, in which pro-inflammatory cytokines are very important $[21,22]$. During activation through the alternative pathway, an IKK (IKB kinase) complex consisting of two IKK $\alpha$ subunits phosphorylates p100, which is the primary gene product encoded by $N F K B 2$, that plays an essential role in many chronic inflammatory diseases $[8$, $23,24]$. In our study such an observation was confirmed, the level of NFKB2 mRNA in peptic ulcer patients was higher than in the control tissue. On the one hand, several factors, such as persistent infections with $H$. pylori the pro-inflammatory microenvironment of the cancer, selfreactive immune receptors as well as genetic lesions altering the function of key signalling effectors, contribute to constitutive NF- $\mathrm{KB}$ activity in these malignancies [9, 25]. On the other, chronic inflammatory microenvironment may lead to immunosuppression and cancer development which can be visible as NF- $\mathrm{KB}$ protein $\mathrm{p} 50$ expression inducing the immunosuppressive microenvironment [26]. In our study no significant differences of the NFKB2 gene relative expression level between the subgroup of patients infected and uninfected with $H$. pylori were observed also no correlation between severity of $H$. pylori infection and NFKB2 mRNA level was found.

The relative expression level of $N F K B 2$ is significantly lower in cancer cases than the control tissue, which could suggest that during carcinogenesis of gastric cancer, inhibition of NF- $\mathrm{KB}$ pathways takes place which could be a promising factor for patients. There are differences important statistically in the investigated gene expression between peptic ulcer and gastric cancer cases and also the control tissue, which could confirm that when peptic ulcer cases its activation, it is connected with the inflammatory process.

This article does not contain any studies with animals performed by any of the authors.

Acknowledgements The authors would like to thank Ms Dorota Jesionek-Kupnicka, PhD.

Funding Research supported by statutory funds of the Department of Pharmaceutical Biochemistry and Molecular Diagnostics, No. 503/3015-02/503-31-001 and by research task of the Medical University of Lodz No. 502-03/3-015-02/502-34-080 and by research task of the Medical University of Lodz No. 502-03/3-015-02/502-34-089. 


\section{Compliance with ethical standards}

Conflict of interest The authors declare that they have no conflict of interest.

Ethical approval All procedures performed in studies involving human participants were in accordance with the ethical standards of the institutional and/or national research committee (The Ethics Committee of the Medical University of Lodz, number (RNN/195/13/KE) and with the 1964 Helsinki declaration and its later amendments or comparable ethical standards.

Informed consent Written informed consent was obtained from the patients prior to their participation in the research.

Open Access This article is licensed under a Creative Commons Attribution 4.0 International License, which permits use, sharing, adaptation, distribution and reproduction in any medium or format, as long as you give appropriate credit to the original author(s) and the source, provide a link to the Creative Commons licence, and indicate if changes were made. The images or other third party material in this article are included in the article's Creative Commons licence, unless indicated otherwise in a credit line to the material. If material is not included in the article's Creative Commons licence and your intended use is not permitted by statutory regulation or exceeds the permitted use, you will need to obtain permission directly from the copyright holder. To view a copy of this licence, visit http://creativecommons.org/licenses/by/4.0/.

\section{References}

1. Karimi P, Islami F, Anandasabapathy Sh, Freedmanand ND, Kamangar F (2014) Gastric cancer: descriptive epidemiology, risk factors, screening, and prevention. Cancer Epidemiol Biomarkers Prev 23:700-713. https://doi.org/10.1158/1055-9965.EPI-13-1057

2. Cavaleiro-Pinto M, Peleteiro B, Lunet N, Barros H (2011) Helicobacter pylori infection and gastric cardiacancer: systematic review and meta-analysis. Cancer Causes Control 22:375-387. doi:https ://doi.org/10.1007/s10552-010-9707-2

3. Kopan R, Ilagan MX (2009) The canonical Notch signaling pathway: unfolding the activation mechanism. Cell 137(2):216-233. doi:https://doi.org/10.1016/j.cell.2009.03.045

4. Lei QY, Zhang H, Zhao B, Zha ZY, Bai F, Pei XH, Zhao S, Xiong Y, Guan KL (2008) TAZ promotes cell proliferation and epithelial-mesenchymal transition and is inhibited by the hippo pathway. Mol Cell Biol 28:2426-2436. doi:https://doi.org/10.1128/ MCB.01874-07

5. Hoesel B 1, Schmid JA (2013) The complexity of NF-кB signaling in inflammation and cancer. Mol Cancer 12:86. doi:https://doi. org/10.1186/1476-4598-12-86

6. Guo X, Koff JL, Moffitt AB, Cinar M, Ramachandiran S, Chen Z, Switchenko JM, Mosunjac MI, Neill SG, Mann KP et al (2017) Molecular impact of selective NFKB1 and NFKB2 signaling on DLBCL phenotype. Oncogene 20(29):4224-4232. doi:https://doi. org/10.1038/onc.2017.90 36) .

7. Oeckinghaus A, Sankar G (2009) The NF-кB family of transcription factors and its regulation. Cold Spring Harb Perspect Biol 1(4):a000034. https://doi.org/10.1101/cshperspect.a000034

8. Israël A (2010) The IKK complex, a central regulator of NF- $\mathrm{KB}$ activation. Cold Spring Harb Perspect Biol 2:a000158. https://doi. org/10.1101/cshperspect.a000158

9. Vallabhapurapu S, Karin M (2009) Regulation and function of NF-kappaB transcription factors in the immune system. Annu Rev
Immunol 27:693-733. doi:https://doi.org/10.1146/annurev.immun ol.021908.132641

10. Spehlmann ME, Eckmann L (2009) Nuclear factor-kappa B in intestinal protection and destruction. Curr Opin Gastroenterol 25:92-99. doi:https://doi.org/10.1097/MOG.0b013e328324f857

11. Kang MJ, Ryu BK, Lee MG, Han J, Lee JH, Ha TK, Byun DS, Chae KS, Lee BH, Chun HS et al (2008) NF- $\kappa B$ activates transcription of the RNA-binding factor HuR, via PI3K-AKT signalling, to promote gastric tumorigenesis. Gastroenterology 135(6):2030-2042. doi:https://doi.org/10.1053/j.gastr o.2008.08.009

12. Livak KJ, Schmittgen TD (2001) Analysis of relative gene expression data using real-time quantitative PCR and the $2-\Delta \Delta \mathrm{Cq}$ method. Methods 25:402-408. doi:https://doi.org/10.1006/ meth.2001.1262

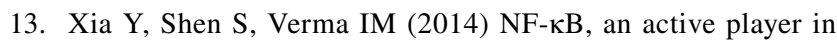
human cancers. Cancer Immunol Res 2:823-830. doi:https://doi. org/10.1158/2326-6066.CIR-14-0112

14. Knittel1 G, Liedgens P, Korovkina D, Pallasch CP, Reinhardt HC (2016) Rewired NFkB signalling as a potentially actionable feature of activated B-cell-like diffuse large B-cell lymphoma. Eur J Haematol 97:499-510. doi:https://doi.org/10.1111/ejh.12792

15. Shaffer AL, Young RM, Staudt LM (2012) Pathogenesis of human B cell lymphomas. Annu Rev Immunol 30:565-610. doi:https:// doi.org/10.1146/annurev-immunol-020711-075027

16. Ni H, Ergin M, Huang Q, Qin JZ, Amin HM, Martinez RL, Saeed S, Barton K, Alkan S et al (2001) Analysis of expression of nuclear factor kappa B (NF-kappa B) in multiple myeloma: downregulation of NF-kappa B induces apoptosis. Br J Haematol 115:279286. doi:https://doi.org/10.1046/j.1365-2141.2001.03102.x

17. Baldwin AS (2001) Control of oncogenesis and cancer therapy resistance by the transcription factor NF-kappaB. J Clin Invest 107:241-246. doi:https://doi.org/10.1172/JCI11991

18. Sovak MA, Bellas RE, Kim DW, Zanieski GJ, Rogers AE, Traish

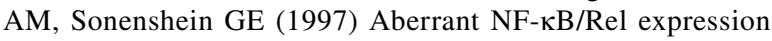
and pathogenesis of breast cancer. J Clin Invest 100:2952-2960. doi:https://doi.org/10.1172/JCI119848

19. Duffey D, Chen Z, Dong G, Ondrey FG, Wolf JS, Brown K, Siebenlist U, Van Waes C (1999) Expression of a dominant negative mutant inhibitor of NF- $\mathrm{\kappa B}$ in human head and neck squamous cell carcinoma inhibits survival, proinflammatory cytokine expression and tumour growth in vivo. Cancer Res 59:3468-3474

20. Basseres DS, Ebbs A, Levantini E, Baldwin AS (2010) Requirement of the NF-kappaB subunit p65/RelA for K-Ras-induced lung tumorigenesis. Cancer Res 70:3537-3546. doi:https://doi. org/10.1158/0008-5472.CAN-09-4290

21. Razani B, Reichardt AD, Cheng G (2011) Non-canonical NFkappaB signaling activation and regulation: principles and perspectives. Immunol Rev 244:44-54. doi:https://doi.org/10.1111/ j.1600-065X.2011.01059.x

22. Fullard N, Wilson CL, Oakley F (2012) Roles of c-Rel signalling in inflammation and disease. Int $\mathrm{J}$ of Biochem Cell Biol 44:851860. doi:https://doi.org/10.1016/j.biocel.2012.02.017

23. Lawrence $\mathrm{T}$ (2009) The nuclear factor NF- $\kappa$ B pathway in inflammation. Cold Spring Harb Perspect Biol 1(6):a001651. https://doi. org/10.1101/cshperspect.a001651

24. Yang X, Sun R, Ci L, Wang N, Yang S, Shi J, Yang H, Zhang M, Fei J (2018) Tracing the dynamic expression of the Nfкb2 gene during inflammatory processes by in vivo bioluminescence imaging in transgenic mice. Biochem Biophys Res Commun 18:41-47. doi:https://doi.org/10.1016/j.bbrc.2018.04.126

25. Grondona P, Bucher P, Schulze-Osthoff K, Hailfinger S, Schmitt A (2018) NF- $\kappa B$ activation in lymphoid malignancies: genetics, signaling, and targeted therapy. Biomedicines 26(6:2):E38. https ://doi.org/10.3390/biomedicines6020038 
26. Porta C, Rimoldi M, Raes G, Brys L, Ghezzi P, Di Liberto D, Dieli F, Ghisletti S, Natoli G, De Baetselier P et al (2009) Tolerance and M2 (alternative) macrophage polarization are related processes orchestrated by p50 nuclear factor kappaB. Proc Natl Acad Sci USA 106:14978-14983. https://doi.org/10.1073/pnas.0809784106
Publisher's Note Springer Nature remains neutral with regard to jurisdictional claims in published maps and institutional affiliations. 